\title{
Etapas da Evolução Político-Administrativa do Brasil
}

Tomás de Vilanova MONTEIRo LOPES

I

O REGIME DAS CAPITANIAS HEREDITÁRIAS

\begin{abstract}
A fórmula jurídica através da qual se constituiam as capitanias hereditárias é de difícil conceituação. Nela divisamos traços característicos de vários institutos, como o usufruto, a concessão de serviço público, a sociedade mercantil de capital misto e a autarquia. Não sendo possível enquadrá-la em nenhuma das categorias jurídicas rigorosamente definidas, deu-se-lhe 0 nome de donatária.
\end{abstract}

A donatária apresentava certa afinidade com o contrato de usufruto, pois que por ela se transmitia o direito de usar a terra e colhêr-lhe os frutos; sem que, todavia, se transmitisse a propriedade. O donatário da capitania hereditária não era proprietário das respectivas terras, as quais continuavam a pertencer à Coroa Portuguêsa, ou mais pròpriamente, à Ordem de Cristo. Mas apesar de tão nítida afinidade, não poderia a donatária ser classificada como usufruto. E que ela apresentava, entre seus característicos fundamentais, ao lado do direito de fruir as utilidades e produtos da terra, uma delegação de poder público, que não caberia nas faculdades normais do usufrutuário. Depois, ao contrário dêste que poderia arrendar o usufruto, o donatário era obrigado, expressamente, sob pena de comisso, a exercer o senhorio das terras que the tocassem.

Não era, também, a donatária uma concessão de serviço público, embora importasse na atribuição a particulares, mediante certas compensações, de serviços que deveriam ser executados pelo poder público. Em realidade se tratava de prestar serviços aos particulares que, como usuários, pagassem pela utflização dos mesmos. Os serviços eram prestados à Coroa, ou seja, à própria autoridade concedente, a qual por êles não ficava obrigada a qualquer pagamento, mas ao contrário adquiria direito à captação de certas rendas e vantagens. Ademais, ao donatário eram conferidos determinados poderes que transbordavam do quadro jurídico da concessão de serviço público.

Com as sociedades mercantis de capitais mistos, a donatária também acusava traços de forte semelhança. Numa como noutras vamos encontrar a associação dos bens das partes interessadas num empreendimento econômico, sob compromisso de distribuição dos rendimentos, numa base prèviamente 
convencionada. Contudo, a donatária, ao contrário da sociedade mercantil, não era entidade privada, mas um instrumento de govêrno e administração.

Pontos de contato bem acentuados davam à donatária a aparência de autarquia, considerada esta como entidade com funções delegadas de poder público, existência autônoma e economia própria. Aos donatários, por delegação expressa da Coroa, cabiam poderes de administração e de govêrno; tais poderes eram exercidos com ampla autonomia, não obstante o vínculo que prendia o donatário ao trono de Portugal. Por outro lado, possuiam as capitanias economia própria, mesmo porque sua instituição visou libertar o erário real do encargo de financiar o povoamento e a colonização das terras do Brasil. Mas, para destruir a significação dos seus traços de semelhança com a autarquia, a donatária era transmissivel por herança, como a propriedade privada, além de que grande parte dos poderes outorgados pelas cartas régias e forais visavam à realização de interêsses pessoais do donatário e não do serviço público.

QUEIROZ LIMA, definindo a donatária como concessão de Estado, parece ter sido quem melhor conseguiu aprender-lhe a natureza jurídica.

As cartas régias e os forais, documentos que dispunham a respeito da criação das capitanias hereditárias e estabeleciam os direitos e deveres dos donatários, sesmeiros e colonos, constituiam, por assim dizer as leis básicas do sistema e eram decalcadas nas ordenações do Reino e nas praxes do comércio com as terras de ultramar. Compreendiam êles preceitos sôbre as seguintes matérias:

1. ${ }^{\mathrm{a}}$ ) Limites e extensão territorial das capitanias;

2. ${ }^{\text {) }}$ Regime jurídico da posse da terra pelo donatário;

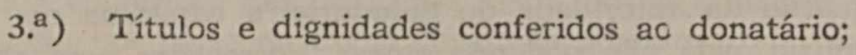

4. a) Relações entre o donatário e a Coroa;

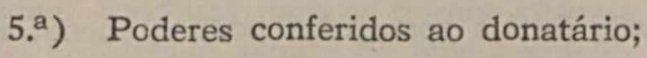

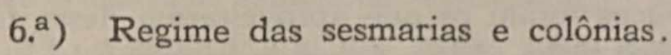

Os limites das capitanias e, portanto, as áreas de govêrno e administração eram estabelecidos, via de regra, tomando-se por pontos de referências certos acidentes geográficos, tais como, rios, baías, angras etc. A extensão media-se em léguas ao longo da costa e para o interior do sertão, até os limites dos domínios da Coroa.

A doação fazia-se com a cláusula de inalienabilidade, não podendo seu objeto ser vendido, trocado ou hipotecado. À Coroa reservava-se o direito de reavê-lo, pela aplicação da pena de comisso, em caso de traição do donatário. Vindo êste a falecer, a capitania transferia-se por herança a um só herdeiro, uma vez que não podia ser partilhada. O princípio adotado na sucessão do dcnatário era o do morgadio, em virtude do qual a herança cabia ao filho varão mais velho. Na ordem vocação hereditária, os descendentes varões, ainda que mais jovens, tinham preferência sôbre os do sexo feminino, salvo se êstes guardassem, em relação ao donatário, um parentesco mais próximo. Os filhos bastardos só teriam direito à herança, na falta de filhos legítimos, 
e depois de provado que a bastardia não provinha de "coito danado", (1) como então se dizia. Os ascendentes e os colaterais, obedecidas as mesmas regras, eram chamados a suceder, no caso de não haver descendentes capazes.

Aos donatários eram conferidos, em caráter perpétuo, os títulos e dignidades de capitão-mor e governador que correspondiam à autoridade suprema da administração militar e da administração civil, respectivamente.

Entre a Coroa e o donatário estabelecia-se um nexo de natureza política, administrativa e moral. Por êle comprometia-se o donatário a submeter-se à Coroa e às leis de Portugal, exercer com lealdade os poderes que the eram conferidos, propagar a fé cristã, conquistar e colocar a serviço do rei novas terras e novas gentes, auxiliar e prestigiar os funcionários incumbidos de zelar pelos interêsses do erário real, assegurar para a Coroa o monopólio do pau brasil, (2) das drogas e especiarias, o quinto dos metais e pedras preciosas, bem como o dízimo de todos os demais produtos da terra.

Como the competisse organizar e manter o aparelhamento de govêrno e administração da capitania, era o donatário cumulado de certos privilégios, através dos quais obteria as rendas de que necessitava para fazer face às suas despesas. Pertencia-lhe o monopólio das marinhas, das moendas d'água e de quaisquer outros engenhos; a vintena de todo pescado; o dízimo do quinto dos metais e pedras preciosas; o redízimo dos produtos da terra; a vintena do pau brasil saído da capitania para ser vendido em Portugal; o direito de escravizar e vender em Lisboa, com isenção de impostos, certo número de indígenas; a liberdade de exportação de produtos para Portugal, mediante o só pagamento da sisa; a cobrança de foros, direitos, tributos e pensões aos sesmeiros, colonos e propostos.

Para maior resguardo da autoridade do donatário, a capitania era considerada lugar de homizio, nela não podendo entrar "corregedor nem alçada nem outras algumas justiças para nelas usar de jurisdição alguma." Graças a isso, os criminosos perseguidos pela justiça portuguêsa podiam encontrar no Brasil um asilo seguro, e não poucos foram os que aproveitaram dessa facilidade. O homizio em terras do Brasil tinha efeitos de verdadeira anistia, exceto para os crimes de heresia, traição, sodomia e moeda falsa, pois os criminosos depois de aqui residirem quatro anos podiam ir ao Reino tratar de seus negócios, pelo prazo de seis meses, sem risco de serem molestados. A prova de residência fazia-se mediante uma guia expedida pelo capitão-mor.

Na sua "qualidade de autoridade suprema do govêrno e da administração da capitania, o donatário tinha competência para:

I - Criar e prover os empregos públicos, inclusive os de alcaides, comandantes militares, ouvidores, escrivães e tabeliães públicos e judiciais;

(1) Segundo as Ordenações, considerava-se danado o coito que importava em incesto, adultério ou quebrado voto religioso de castidade; e os filhos dêle resultantes diziam-se incestuosos, adulterinos ou sacrílegos, conforme o caso.

(2) Êsse monopólio era estabelecido sob as penas de confisco e de degrêdo perpétuo em São Tomé. (Vide a cláusula 3 do Foral da Capitania da Bahia). 
II - Estabelecer e arrecadar os impostos e contribuições relativos aos bens e atividades compreendidos no âmbito de seus monopólios e privilégios;

III - Processar e julgar as questōes cíveis, com alçada para decisão definitiva das causas de valor näo excedente de cem mil réis;

$\mathrm{V}$ - Superintender as eleições de juizes, vereadores e oficiais, bem como homologar os respectivos resultados;

VI - Julgar os crimes, podendo aplicar inclusive a pena de morte, salvo se os réus fôssem fidalgos;

VII - Conceder sesmarias, a quem as requeresse provando ser cristão. (3)

Tais poderes, que já eram muito amplos, na prática se tornavam absolutos, porque os donatários, escudados na fôrça de que dispunham e reconhecendo a ineficiência do contrôle que a tão grande distância sôbre êles poderia exercer a Coroa, agiam a seu bel prazer.

Todos êsses inconvenientes provinham do fato de se haver transplantado para o Brasil um esquema de administração moldado pelo que vigorava na Côrte. A adaptação dêsse esquema às diferentes regiões do Brasil processou-se de maneira heterogênea, ao sabor das circunstâncias, por falta de um instrumento de coordenação capaz de disciplinar e imprimir unidade à ação dos donatários. Daí resuitaria, com o correr dos tempos, um confuso emaranhado de normas, praxes e soluções de contingência, que tanto dificulta o estudo de nossa administração pública do período colonial.

Uma constatação, entretanto, pode ser feita sem grande esfôrço. É a de que no regime das capitanias hereditárias, o aspecto que mereceu maiores cuidados por parte da Coroa foi o relacionado com os interêsses do fisco. A propósito instituiu-se, desde logo, um sistema que pela sua simplicidade e rigidez contrasta com os têrmos vagos e tumultuários das disposições referentes aos demais setores da administração. De acôrdo com o aludido sistema:

a) o proprietário das terras onde houvesse pedrarias, pérolas, aljôfar, ouro, prata ou qualquer outro metal, pagava ao rei o quinto arrecadado e o dízimo dêste ao capitão-mor;

b) os moradores pagavam ao rei a dízima e ao capitão a meia dízima do pescado;

c) os produtos da capitania (excetuado o pau brasil que era monopólio da Coroa) podiam ser livremente exportados, uma vez paga a sisa, na ocasião da venda;

d) as mercadorias importadas da metrópole pagavam direitos nas alfândegas do reino, e as certidões por estas expedidas isentavam do pagamento do direito de entrada na colônia;

(3) A sesmaria era concedida em propriedade alodial, sujeita, apenas, ao pagamento da dízima da Ordem de Cristo e à observância dos monopólios reais e das servidões. Na conformidade das Ordenações Manoelinas, o sesmeiro ficava obrigado a beneficiar a terra, no prazo de cinco anos, sob a cominação de confisco e multa. 
e) os gêneros exportados pelo Brasil ficavam sujeitos ao pagamento da dízima ao rei, e da redízima ao capitão-mor, mas não pagavam direitos alfandegários, quando se destinavam a Portugal ou aos domínios portuguêses de ultramar;

f) ao comerciante estrangeiro cobrava-se a dízima sôbre as mercadorias duas vêzes, à saída e à entrada no Brasil, e vice-versa.

Como fôra inicialmente concebido, o regime das capitanias hereditárias compreendia dois ramos: o da metrópole e o da colônia, sendo o segundo subordinado ao primeiro que era, por assim dizer, a cúpula. $\mathrm{Na}$ metrópole havia o Rei, seus Ministros e Conselheiros. Na colônia, diretamente subordinados à Coroa, havia, de um lado o donatário, com os títulos e dignidades de Capitão-Mor e Governador, e, de outro, os funcionários do reino, como os almoxarifes, escrivães e demais agentes do fisco, erscarregados de arrecadar os direitos das alfândegas, os quintos dos metais e pedras preciosas, os dízimos de todos os produtos da terra e os direitos do monopólio do pau brasil. (4)

O govêrno colonial pròpriamente dito comportava três campos: o militar, o administrativo e o econômico-social. Todos êles eram dominados pela figura do donatário, representante do rei nas terras de sua jurisdição.

No campo militar tinha-se como autoridade suprema o capitão-mor e subordinados a êle, os comandantes militares das vilas, os chefes das casas de armas e o pessoal das tropas.

No campo administrativo tinha-se, em primeiro plano, a figura do governador, ao qual eram subordinados os alcaides, a Câmara com funções legislativas e judiciárias, os ouvidores, os escrivães, os meirinhos, os tabeliães, os coletores de impostos e demais agentes da administração civil. As funções públicas, em sua maioria, ou eram exercidas gratuitamente, como as de vereador e juiz de fora, ou remuneradas com as taxas e contribuições cobradas pelos serviços prestados aos particulares. Os funcionários pagos pela capitania, os chamados "filhos da fôlha", não passavam de número assaz reduzido.

No campo sócio-econômico, tinha-se abaixo do donatário o colono e em seguida o peão. O colono, seus filhos e dependentes eram obrigados a pagar ao donatário os foros, tributos e senhorios previstos nas Ordenaçöes, inclusive o tributo de sangue, em caso de guerra.

- O exercício da autoridade pelos órgãos e prepostos da administração constituia o ponto mais vulnerável do sistema pois carecia de ordem, de uniformidade, de clareza. Eram raríssimas as normas gerais sôbre serviços públicos, de sorte que os problemas iam sendo resolvidos conforme as circunstâncias e os interêsses do momento. A administração parecia mais um negócio privado do que, pròpriamente, uma fundação do Estado. $\mathrm{O}$ interêsse público só era atendido nas raras ocasiões em que coincidia com o donatário ou os dos senhores rurais. O sentimento de propriedade pessoal com que se concebia e conduzia a administração afastava qualquer preocupação pela

(4) As nomeações dêsses funcionários faziam-se através đee cartas-régiss, das quais ficava registro no Livro das Provisões, e a entrada em exercício era assinalsda por um têrmo lavrado no Livro das Vereações. 
regularidade e sistematização dos atos de govêrno. As decisões orais eram largamente empregadas, o que explica a inexistência de documentos a respeito de muitos aspectos da vida administrativa de então. Comuns se revelam os excessos e abusos de poder, porque o mecanismo de contrôle dos atos da administração não poderia ser mais precário. As freqüentes invasões da esfera de competência de umas autoridades pelas outras criavam conflitos que se resolviam pelo critério da fôrça ou da influência pessoal.

Nos seus aspectos estruturais, o govêrno e administração das capitanias hereditárias apresentam alguma ordem e coerência; seu funcionamento, porém, era tumultuário, desconexo, dando perfeita idéia daquele imenso caus, a quẻ se refere CAIO PRADO Júnior. (5)

Como se tanto não bastasse, as capitanias comportavam-se umas em relação às outras como pequenas nações independentes, e às vêzes hostis. A distância em que se achavam da Côrte e a necessidade com que não raro se defrontavam de adotar medidas de emergência que não podiam aguardar as instruções da Metrópole, foram criando da parte dos donatários um espírito de auto-suficiência, o qual, estimulado pelos poderes absolutos a que já nos referimos, cedo se transformou em indisciplina e rebeldia. Para fazer face a essa situaçâo a Coroa recorreu à fórmula do govêrno geral.

E oportuno lembrar que a instituição do Govêrno Geral não pôs fim ao regime das capitanias hereditárias, pois estas subsistiram ainda por largo tempo, até sua reversão ao Estado, já na administração do MARQUÊS DE Pombal. Mas desde que se constituiu o Govêrno Geral foi pràticamente abolida a concessão de novas donatárias, passando-se a adotar a praxe da criação de "Capitanias da Coroa", que eram administradas por um governador nomeado em Lisboa.

(5) Fcrmação do Brasil Contemporâneo. 